\title{
ANTIGENIC EVALUATION OF MYCOBACTERIUM LEPRAEMURIUM
}

\author{
R. G. Navalkar, Rekha R. Dalvi and P. J. Patel \\ Department of Microbiology, Meharry Medical College, \\ Nashville, Tennessee 37208, USA
}

\begin{abstract}
IMMUNOLOGICAL studies on Mycobacterium lepraemurium have been limited mainly because of the problems involved in growing the organism in vitro. Although growth studies in tissue culture (Rees and Wong, 1958; Wallace, Elek and Hanks, 1958; Rees and Garbutt, 1962; Chang, Anderson and Vaituzis, 1967) and metabolic studies on the organism (Tepper and Varma, 1972) have been reported, very few investigations on the antigenic mosaic of this organism have been carried out on tissue-separated bacilli (Rees and Tee, 1962; Fukui et al., 1966; Kwapinsky et al., 1972; Stanford, 1973). The present study was undertaken to evaluate the antigenic make-up of the organism and to determine the number of antigens it shares with other mycobacterial species.
\end{abstract}

\section{MATERIALS AND METHODS}

Mycobacterial strains. The strains used were: M. lepraemurium (Hawaii), M. johnei, $M$. leprae, $M$. avium (nos. 2, 11 and 29), $M$. intracellulare (nos. 5, 14 and 56), $M$. kansasii (no. ATCC24178), M. marinum (no. 691), M. smegmatis (no. NCTC8159) and $M$. tuberculosis (no. $\mathrm{H}_{37} \mathrm{Rv}$ ). The first three organisms listed were separated from infected tissue and the remainder were grown in vitro.

Preparation of culture filtrate $(C F)$. Culture filtrates were obtained from $M$. smegmatis, $M$. kansasii, $M$. marinum, and all the strains of $M$. avium and $M$. intracellulare. The strains were grown on Sauton's (1912) medium under static conditions.

Initial transfers were made from growth on Lowenstein-Jensen medium into DubosMiddlebrook (DM) broth containing Tween 80 and Dubos medium albumin as supplement. The incubation temperature for all strains was $37^{\circ} \mathrm{C}$. M. marinum was also grown at $30^{\circ} \mathrm{C}$. After incubation for 7 days, the growth from the DM broth was transferred to 250-ml conical flasks containing $100 \mathrm{ml}$ of Sauton's medium and the flasks were incubated for 4 weeks before final transfer into fresh Sauton's medium. The cultures were allowed to grow for 6 weeks, after which the surface pellicles were separated from the CF by means of Buchner funnels. The cells were collected, washed in $0.15 \mathrm{M}$ sodium chloride and stored at $-20^{\circ} \mathrm{C}$ for future use.

$\mathrm{CF}$, sterilised by Seitz filtration, was transferred to a pre-sterilised dialysis bag for pervaporation at room temperature. Pervaporation was interrupted after $24 \mathrm{~h}$ to permit dialysis overnight against running cold tap water. Intermittent pervaporation and dialysis were carried out until each $C F$ was concentrated to approximately one-twentieth of its original volume. Upon completion of sterility tests, each concentrated CF containing 1 in 10,000 merthiolate was stored at $-20^{\circ} \mathrm{C}$ until used.

A concentrated CF from $M$. tuberculosis strain $\mathrm{H}_{37} \mathrm{Rv}$, was obtained from the US-Japan Tuberculosis Panel Committee on Antigens (Janicki et al., 1971).

Preparation of cell extract (CE). Cell extracts from mechanically disrupted cells were obtained from all the mycobacterial strains except $M$. tuberculosis.

For the preparation of extracts of mycobacteria grown in vitro, the stored cells mentioned above were thawed and washed three times in $0 \cdot 15 \mathrm{M}$ sodium chloride. At the end of the third washing, the pellet was weighed and the moist cells were resuspended in isotonic saline at a concentration of $12 \mathrm{mg}$ per $\mathrm{ml}$. The resulting suspension was homogenised in a teflon 
grinder, and then disrupted in a refrigerated cell-fractionator (Sorvall) at $276,000 \mathrm{kN} / \mathrm{m}^{2}$. The material was then stored at $-20^{\circ} \mathrm{C}$ after the addition of merthiolate.

A similar method was used to prepare CE from $M$. lepraemurium, M. johnei and $M$. leprae grown in vivo. The method for separation of $M$. leprae obtained from human leproma has been described in a previous publication (Navalkar, 1971). The $M$. lepraemurium cells were obtained from Dr B. S. Tepper, whose method of separation has been described elsewhere (Tepper and Varma, 1972). The $M$. johnei was separated from infected bovine intestinal mucosa in the laboratory of Dr R. Merkal.

Preparation of antisera. Antisera were prepared against CF of M. smegmatis, M. avium, $M$. kansasii and $M$. marinum and against all CE preparations. Antiserum to the CF of $M$. tuberculosis was obtained from the same source as its corresponding antigen (see above). After the collection of a serum sample, male rabbits, weighing 1.5 to $2 \mathrm{~kg}$ were inoculated with $1 \mathrm{ml}$ of a mixture of equal volumes of CF or CE with Freund's incomplete adjuvant. The animals were given weekly subcutaneous injections for 6 weeks. Three rabbits were used for each preparation. One week after the last injection, serum was collected to determine by immunodiffusion analysis the level of antibodies in each rabbit. Only rabbits that showed satisfactory and identical antibody responses to any immunising preparation were used to supply serum; they were exsanguinated a week after the preliminary sample had been taken and their serum was pooled. Serum was stored at $-20^{\circ} \mathrm{C}$ after addition of merthiolate.

Serological tests. The comparative immunodiffusion technique of Ouchterlony (1962) as modified by Hanson (1959) was used to analyse the various sera and to determine the antigenic constituents.

\section{Lepraemurium}

\section{M. smegmatis*}

M. kansasii

M. marinum (grown at $30^{\circ} \mathrm{C}$ ) M. marinum (grown at $37^{\circ} \mathrm{C}$ ) *

M. Ieprae

M. johnei

M. avium (no. 2)*

M. avium (no.11)*

M. avium (no. 29)*

$M$. intracellulare (no.5) $\dagger$

M. intracellulare (no.14) $\dagger$

$M$. intracellulare (no.56) †

M. tuberculosis (strain $\mathrm{H}_{37} \mathrm{Rv}$ ) *

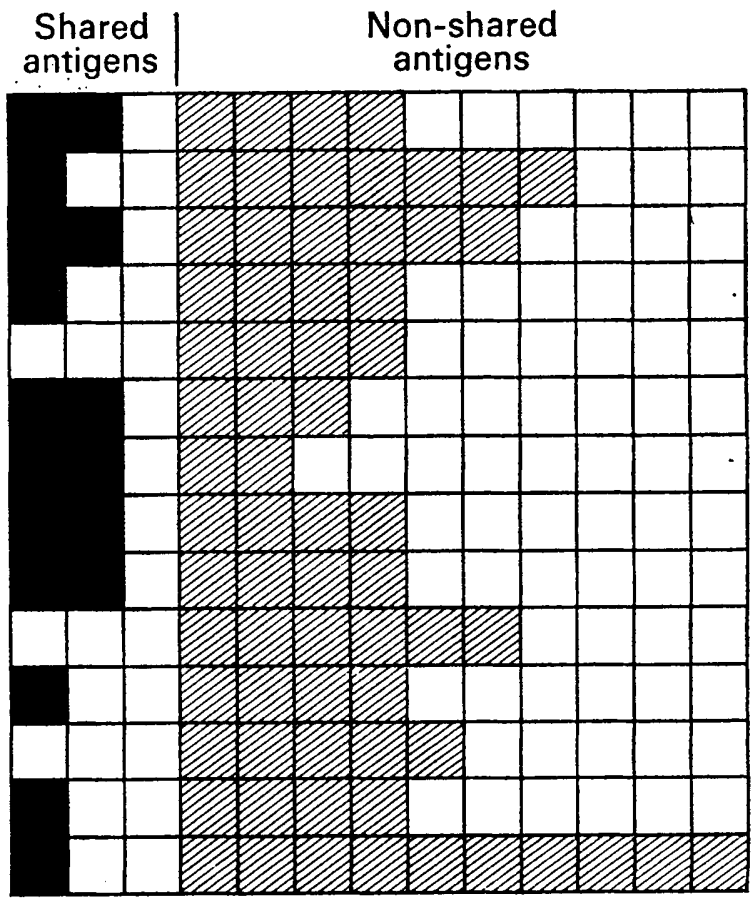

FIGURE.-Antigenic relationship between Mycobacterium lepraemurium and other mycobacteria. Shared antigens are indicated by dark squares and non-shared by hatched ones. All strains except $M$. tuberculosis (strain $\mathrm{H}_{37} \mathrm{Rv}$ ) were examined as $\mathrm{CE}$ preparations. ${ }^{*}=$ Also examined as $\mathrm{CF}$ preparation. $t=$ As no corresponding antisera were raised against the CF preparations, results obtained with the CE preparations only are given. 


\section{RESULTS}

As a first step toward recognising the various antigens of $M$. lepraemurium, the CE was tested by means of the immunodiffusion technique against the corresponding antiserum prepared in rabbits. Six lines of precipitation were observed, indicating at least six antigens. The next step was to determine by means of comparative immunodiffusion analysis the number of antigens shared by $M$. lepraemurium and other mycobacterial species.

The figure summarises the results of these studies. $M$. lepraemurium shared one of its antigens with $M$. smegmatis, $M$. marinum grown at $30^{\circ} \mathrm{C}, M$. intracellulare (two strains of the three examined) and $M$. tuberculosis, and two of its antigens with $M$. leprae, $M$. johnei, $M$. kansasii and $M$. avium (two of the three strains examined). It is interesting that $M$. marinum grown at $37^{\circ} \mathrm{C}$ and one strain each of $M$. intracellulare and $M$. avium did not share any antigens with $M$. lepraemurium. The results given are those obtained with the concentrated $C F$ of some strains and the $C E$ of all the strains. No significant differences were noted when both CF and CE preparations were used.

\section{Discussion}

$M$. lepraemurium appeared to share some of its six demonstrable antigens with other mycobacteria. Of the two antigens shared with $M$. leprae, $M$. johnei, M. kansasii and $M$. avium, one appeared to be shared also with $M$. smegmatis, $M$. marinum, $M$. tuberculosis and $M$. intracellulare. This antigen is apparently the one that has been described by Navalkar, Norlin and Ouchterlony (1964) and Norlin (1965) as the $\beta$-antigen and that has been shown to be shared by most mycobacteria.

Stanford (1973) studied six strains of $M$. lepraemurium, one being the Hawaiian strain studied by us. He stated that all the strains possessed at least ten antigens, five of which were shared with the majority of mycobacterial species. He also stated that $M$. lepraemurium shared eight antigens with $M$. avium and that it could be considered a serotype or subspecies of $M$. avium.

Our studies differ from those of Stanford (1973) in respect of the number of detectable antigens of $M$. lepraemurium, and the number of antigens shared with other mycobacteria, particularly $M$. avium. Differences were also noted in the total number of antigens demonstrated in the various species studied. Our data, however, closely parallel those of Norlin (1965). The variations between the results obtained in different laboratories may be related to the methods used. Regardless of the number of antigens shared, the fact that $M$. lepraemurium does possess antigens common to other mycobacteria has been confirmed by this investigation. Similar observations have also been reported by others; thus Rees and Tee (1962) stated that rabbit antisera prepared against a number of mycobacteria reacted with $M$. lepraemurium antigen, and Fukui et al. (1966) demonstrated that $M$. lepraemurium possessed the $\alpha$-antigen that resembled an antigen present in $M$. avium, an observation similar to that made by Stanford (1973).

Our work does not indicate a close relationship between $M$. avium and $M$. lepraemurium, because the antigens shared by the two organisms were also shared by several other mycobacteria representing both slowly and rapidly growing types. It is, however, likely that such a relationship exists, because, in recent studies on the base composition of DNA isolated from strains of $M$. avium and M. lepraemurium, Tepper (personal communication, 1972) has found that the guanine-plus-cytosine values of the DNA derived from these organisms fall in the range of $68 \cdot 5-70 \cdot 0 \%$. Similar studies by Wayne and Gross (1968) showed a bimodal clustering within the genus Mycobacterium.

One of the conclusions that can be drawn from our studies is that $M$. lepraemurium does possess the antigen most commonly shared between various mycobacterial species, namely, the $\beta$-antigen described by Norlin (1965). It is likely that this is an antigen similar to the $\alpha$-antigen described by Fukui et al. (1966). 


\section{SUMMARY}

Immunodiffusion analysis of Mycobacterium lepraemurium indicated the presence of at least six antigens. Comparative analysis of the $M$. lepraemurium antigen-antibody system with similar systems established for other mycobacterial species, showed that $M$. lepraemurium shared up to two antigens with other species.

Although our observations are in accord with some of the studies on the antigenic mosaic of $M$. lepraemurium, they are in disagreement with the observations of Stanford (1973) concerning a close serological relationship of this organism to $M$. avium. This incompatibility cannot be explained satisfactorily at present.

We wish to thank Dr B. S. Tepper of the Johns Hopkins-Leonard Wood Memorial Leprosy Research Laboratory, Baltimore, Maryland, for supplying M. lepraemurium, Dr R. Merkal of the National Animal Diseases Laboratory, US Department of Agriculture, Ames, Iowa, for supplying the M. ohnei and Dr L. Levy of the United States Public Health Service Hospital, San Francisco, for the other mycobacterial strains used in this study. Our thanks are also due to the US-Japan Tuberculosis Panel's Antigen Committee for supplying the $M$. tuberculosis $\left(\mathrm{H}_{37} \mathrm{Rv}\right)$ reference system.

This investigation was supported by the United States-Japan Cooperative Medical Sciences Program administered by the National Institutes of Allergy and Infectious Diseases of the National Institutes of Health, Education and Welfare (grant no. AI-08647), Bethesda, Maryland 20014, USA.

\section{REFERENCES}

Chang, Y. T., ANderson, R. N. AND VaItuzis, Z. 1967. Growth of Mycobacterium lepraemurium in cultures of mouse peritoneal macrophage. J. Bact., 93, 1119.

Fukui, Y., Mori, T., Kohsaka, K., Nishimura, S. AND YonedA, M. 1966. Antigenic structure of Mycobacterium lepraemurium. 1. Presence of avian type antigen in strains of M. lepraemurium. Biken J., 9, 63.

HANSON, L. $\AA$. 1959. Immunologic analysis of streptoccal antigens and human sera by means of diffusion-in-gel methods. Int. Archs Allergy appl. Immun., 14, 270.

Janicki, B. W., Chaparas, S. D., Daniel, T. M., Kubica, G. P., Wright, G. L. AND YEE, G. S. 1971. A reference system for antigens of Mycobacterium tuberculosis. Am. Rev. resp. Dis., 104, 602.

Kwapinski, J. B. G., AlCasid, A., Kwapinski, E. H. AND NAIRN, V. 1972. The immunology of cytoplasmic antigens of mycobacteria. Can. J. Microbiol., 18, 1201.

NaVAlKar, R. G. 1971. Immunologic analysis of Mycobacterium leprae antigens by means of diffusion-in-gel methods. Int. J. Lepr. 39, 105.

NavalkaR, R. G., Norlin, M. AND OuChTERLONY, Ö. 1964. Characterization of leprosy sera with various mycobacterial antigens using double diffusion-in-gel analysis. Int. Archs Allergy appl. Immun., 25, 103.

Norlin, M. 1965. Unclassified mycobacteria. A comparison between a serological and biochemical classification method. Bull. Un. int. Tuberc., 36, 25.

OuCHTERLONY, Ö. 1962. Diffusion-in-gel methods for immunologic analysis II. Prog. Allergy, 6, 30.

Rees, R. J. W. AND Garbutt, E. W. 1962. Studies on Mycobacterium lepraemurium in tissue culture. 1. Multiplication and growth characteristics in cultures of rat fibroblasts. Br. J. exp. Path., 43, 221.

Rees, R. J. W. AND TeE, R. D. 1962. Studies on Mycobacterium lepraemurium in tissue culture. II. The production and properties of soluble antigens from Mycobacterium lepraemurium in tissue culture. Br.J. exp. Path., 43, 480.

ReEs, R. J. W. AND WoNG, P. C. 1958. Limited multiplication of Mycobacterium lepraemurium in tissue culture. Nature, Lond., 181, 359.

SAuton, M. B. 1912. Sur la nutrition minéral du bacille tuberculeux. C.r. hebd. Séanc. Acad. Sci., Paris, 155, 860. 
STANFORD, J. L. 1973. An immunodiffusion analysis of Mycobacterium lepraemurium Marchoux and Sorel. J. med. Microbiol., 6, 435.

TEPPER, B. S. AND VARMA, K. G. 1972. Metabolic activity of purified suspensions of Mycobacterium lepraemurium. J. gen. Microbiol., 73, 143.

Wallace, J. H., EleK, S. D. ANd HaNKs, J. H. 1958. Limited multiplication of Mycobacterium lepraemurium in cell cultures. Proc. Soc. exp. Biol. Med., 97, 101.

WAYNE, L. G. AND Gross, W. M. 1968. Base composition of deoxyribonucleic acid isolated from mycobacteria. J. Bact., 96, 1915. 